Article

\title{
Effects of Amendments on Soil Microbial Diversity, Enzyme Activity and Nutrient Accumulation after Assisted Phytostabilization of an Extremely Acidic Metalliferous Mine Soil
}

\author{
Sheng-xiang Yang ${ }^{1,2}$, Bin Liao ${ }^{2}$, Rong-bo Xiao ${ }^{3, *}$ and Jin-tian $\mathrm{Li}^{2,4, *}$ \\ 1 College of Resources and Environment and Key Laboratory of Soil Resources and Environment in Qianbei of \\ Guizhou Province, Zunyi Normal University, Zunyi 563006, China; yangsx1998@163.com \\ 2 School of Life Sciences and State Key Laboratory of Biocontrol, Sun Yat-sen University, Guangzhou 510275, \\ China; Liaobin2005@126.com \\ 3 School of Environmental Science and Engineering, Guangdong University of Technology, \\ Guangzhou 510006, China \\ 4 Institute of Ecological Science, School of Life Sciences, South China Normal University, \\ Guangzhou 510631, China \\ * Correspondence: ecoxiaorb@163.com (R.X.); lijtian@mail.sysu.edu.cn (J.L.); Tel.: +86-20-85211850 (J.L.)
}

Received: 17 February 2019; Accepted: 9 April 2019; Published: 15 April 2019

\begin{abstract}
Current criteria for successful phytostabilization of metalliferous mine wastelands have paid much attention to soil physico-chemical properties and vegetation characteristics. However, it remains poorly understood as to how the soil microbial community responds to phytostabilization practices. To explore the effects of amendments on the microbial community after assisted phytostabilization of an extremely acidic metalliferous mine soil $(\mathrm{pH}<3)$, a pot experiment was performed in which different amendments and/or combinations including lime, nitrogen-phosphorus-potassium (NPK) compound fertilizer, phosphate fertilizer and river sediment were applied. Our results showed the following: (1) The amendments significantly increased soil microbial activity and biomass C, being 2.6-4.9 and 1.9-4.1 times higher than those in the controls, respectively. (2) The activities of dehydrogenase, cellulase and urease increased by $0.9-7.5,2.2-6.8$ and 6.7-17.9 times while acid phosphatase activity decreased by $58.6 \%-75.1 \%$ after the application of the amendments by comparison with the controls. (3) All the amendments enhanced the nutrient status of the mine soil, with organic matter, total nitrogen and total phosphorus increased by 5.7-7.8, 3.1-6.8 and 1.1-1.9 times, relative to the mine soil. In addition, there were strong positive correlations between soil microbial community parameters and nutrient factors, suggesting that they were likely to be synergistic. From an economic view, the combination of lime $\left(25 \mathrm{tha}^{-1}\right)$ and sediment from the Pearl River ( $\left.30 \%\right)$ was optimal for functional rehabilitation of the microbial community in the extremely acidic metalliferous mine soil studied.
\end{abstract}

Keywords: acidic metalliferous mine soil; amendments; enzyme activity; microbial community; nutrients

\section{Introduction}

Mining can transform fertile, cultivated land into unfertile land. One way is by altering the structural and function of the soil microbial community [1,2]. Remediation of mine wastelands is one of the pressing needs to be addressed for social and economic development to be healthy and sustainable. The ultimate goal of mine land remediation is therefore the re-establishment of a productive, healthy and sustainable ecosystem for post-mining land use [3]. Currently, criteria for successful remediation have paid much attention to soil erosion, physico-chemical properties of the substrate and 
vegetation characteristics [4,5]. It should be noted, however, that soil microbial community is of critical importance for the ecological functioning of an ecosystem such as nutrient cycling, plant establishment, geochemical transformations, and soil formation. In this sense, soil microbial community properties should be considered also as important criteria for evaluating the success of remediation schemes for mine sites [6]. Therefore, more emphasis must be given to understanding the roles of the mine soil microbiota for developing sustainable remediation [7-9]. Soil enzymes are associated with the proliferation of soil microbial communities. Their activities integrate information about microbial status and soil physico-chemical conditions and are indicators of the functioning of soil ecosystems [6]. Soil enzyme activities have similarly been used in studies on the effectiveness of remedial treatments on soil quality. Dehydrogenase is an oxido-reductase enzyme which has been used as a measure of overall microbial activity [10]. Cellulase, urease and phosphatase, related to the cycles of C, N and P, are sensitive indicators of management-induced changes due to their strong relationships with soil quality [11,12]. Dehydrogenase, cellulase, urease and phosphatase activities have all been reported as indicators of progress in soil-remediation processes of mine soils [13,14]. In addition, the activity of acid phosphatases may be a useful bioindicator for monitoring the soil quality of acidic, P-deficient substrates [15]. To date, several researches have shown that the addition of inorganic and organic materials either stimulated soil microbial activity, or increased soil microbial diversity, microbial biomass, enzyme activity and nutrient status [7]. However, previous studies have rarely explored the effects of amendments on these microbe-related parameters simultaneously, representing a knowledge gap in the field.

Sulphidic mine soils represent a typical anthropogenic extreme environment, as indicated by the much lower diversity of dwelling microbial communities relative to natural soils [16]. Dabaoshan pyrite/copper mine is a representative polymetallic mine located in Guangdong Province, southern China. Mining activities here have generated large quantities of pyrite-rich deposits discarded on the mine site. Metal sulphides in the mine soil have undergone oxidation and hydrolysis and generated large quantities of acidity which resulted in the $\mathrm{pH}$ of the mine soil lowered rapidly and metal ions released at extremely phytotoxic levels [17]. Acidification and heavy metal toxicity act synergistically under natural conditions, which collectively can degrade the biological properties of mine soils including nutrient depletion and changes in the microbial community [18]. Traditionally, remediation studies on acidic, metal-contaminated mine wastelands have focused on the determination of changes in the extent of acidification and the available heavy metal pool [17]. However, the effectiveness of remedial practices on the soil microbial community and nutrient element bioavailability is generally limited. Further studies are therefore needed to determine the potential of any improved remediation strategy for the restoration of soil microbial properties and nutrient status enhancement.

The main aim of the present study was to determine the effects of amendments (including lime, NPK compound fertilizer, phosphate fertilizer and river sediment) on the soil microbial biomass, diversity, community structure, enzyme activity and nutrient element status in an extremely acidic metalliferous mine soil systematically. We hypothesized that any amendment employed would increase soil fertility and enhance microbial functionality. To test this hypothesis, we determined and compared the effects of the amendments on soil microbial diversity, biomass carbon (C), enzyme activities and nutrient elements, all of which could have implications for further development of effective remediation practices of this widespread and typical mining wasteland.

\section{Materials and Methods}

\subsection{Experimental Design}

Six hundred kilograms of an acidic metal-contaminated mine soil (0-20 cm in depth) was obtained from an abandoned area of Dabaoshan pyrite/copper mine. Detailed information about the acidification properties and heavy metal concentrations in this mine soil were reported in our previous study [17]. To correct the soil acidity, two levels of lime $\left(25 \mathrm{t} \mathrm{ha}^{-1}\right.$ and $\left.50 \mathrm{t} \mathrm{ha}^{-1}\right)$ were applied according to the 
soil lime requirement to produce final pHs of 5 and 7, respectively. Lime, NPK compound fertilizer $\left(\mathrm{N}-\mathrm{P}_{2} \mathrm{O}_{5}-\mathrm{K}_{2} \mathrm{O}=15: 15: 15\right)$, phosphate fertilizer and river sediment were applied as amendments in this study. The lime and fertilizers were produced by Shijiazhuang Sanyuan Compound Fertilizer Plant. Sediment from the Pearl River was collected from the place without water cover. The mine soil and river sediment were air-dried, thoroughly homogenized, sieved $(5 \mathrm{~mm})$ and stored in the laboratory for 6 months before pot experiment started. Selected physico-chemical properties of the mine soil and river sediment are shown in Table 1 . The mine soil, lime, NPK compound fertilizer, phosphate fertilizer and river sediment were mixed at pre-determined ratios which were presented in Table 2 . Two controls without amendments [control1 (mine soil) and control2 (mine soil + sawdust)] were also established. $200 \mathrm{~g}$ dry sawdust was applied to all the soil treatments to improve porosity, except for control1. All the treatments were replicated four times with four pots $(1.7 \mathrm{~kg}$ per pot $)$ and placed in a glasshouse, where day/night temperatures were maintained at $22-30 / 10-16{ }^{\circ} \mathrm{C}$. The soil mixtures were then adjusted to $70 \%$ of their maximum water holding capacity and allowed to equilibrate for 2 weeks prior to sowing. A mixture of seeds of Sebania cannabina Poir., (10 seeds per pot) Lygeum spartum Loefl.ex L. (20 seeds per pot) and Cynodon dactylon (L.) Pers. (30 seeds per pot) were sown on each pot. The pots were watered once three days to maintain their initial water content and the plants allowed to grow for 6 months in the glasshouse (Figure S1, Supplementary information). At the end of this growth period, plants were carefully removed from the pot and all the soil in the pot was collected. The soil samples from each treatment were divided into two subsamples. One fresh subsample was stored at $4{ }^{\circ} \mathrm{C}$ for microbial community and enzyme analysis within two weeks; the other subsample was air-dried and subjected to chemical analysis.

Table 1. Selected physico-chemical properties of the mine soil and river sediment used in the pot experiment.

\begin{tabular}{ccc}
\hline Parameters & Mine Soil & River Sediment \\
\hline Sand (\%) & $82.2 \pm 9.7$ & nd \\
Slit (\%) & $10.1 \pm 0.89$ & nd \\
Clay (\%) & $7.5 \pm 0.43$ & nd \\
pH & $2.5 \pm 0.14$ & $7.3 \pm 0.29$ \\
Electrical conductivity $\left(\mathrm{dS} \mathrm{m}^{-1}\right)$ & $3.1 \pm 0.18$ & $1.6 \pm 0.13$ \\
Organic matter $\left(\mathrm{g} \mathrm{kg}^{-1}\right)$ & $6.2 \pm 0.53$ & $70.6 \pm 12.1$ \\
Total nitrogen $\left(\mathrm{mg} \mathrm{kg}^{-1}\right)$ & $44.5 \pm 3.6$ & $1054 \pm 88.1$ \\
Total phosphate $\left(\mathrm{mg} \mathrm{kg}^{-1}\right)$ & $307 \pm 25.2$ & $722 \pm 53.2$ \\
Total potassium $\left(\mathrm{mg} \mathrm{kg}^{-1}\right)$ & $290 \pm 16.4$ & $2717 \pm 217$ \\
Zinc $\left(\mathrm{Zn}, \mathrm{mg} \mathrm{kg}^{-1}\right)$ & $1175 \pm 84.1$ & $147 \pm 16.8$ \\
Lead $\left(\mathrm{Pb}, \mathrm{mg} \mathrm{kg}^{-1}\right)$ & $1107 \pm 67.9$ & $75.1 \pm 10.4$ \\
Copper $\left(\mathrm{Cu}, \mathrm{mg} \mathrm{kg}^{-1}\right)$ & $1826 \pm 121$ & $50.4 \pm 8.8$ \\
Cadmium $\left(\mathrm{Cd}, \mathrm{mg} \mathrm{kg}^{-1}\right)$ & $2.6 \pm 0.33$ & $0.76 \pm 0.01$ \\
\hline
\end{tabular}

nd: not detected

Table 2. Experimental design for pot experiment.

\begin{tabular}{|c|c|c|}
\hline $\begin{array}{l}\text { Treatment } \\
\text { types }\end{array}$ & Treatments & Amendments \\
\hline CK & $\begin{array}{l}\text { control1 } \\
\text { control2 }\end{array}$ & $\begin{array}{c}\text { mine soil } \\
\text { mine soil + sawdust * }\end{array}$ \\
\hline L1 & $\begin{array}{c}\text { lime1 } \\
\text { lime1+NPK } \\
\text { lime } 1+\mathrm{P} \\
\text { lime } 1+\mathrm{Rs} \\
\text { lime } 1+\mathrm{NPK}+\mathrm{Rs}\end{array}$ & $\begin{array}{c}\text { mine soil }+ \text { lime1 }\left(25 \mathrm{t} \mathrm{ha}^{-1}\right) \\
\text { mine soil + lime1 }\left(25 \mathrm{tha}^{-1}\right)+\text { NPK compound fertilizer }\left(150 \mathrm{~kg} \mathrm{ha}^{-1}\right) \\
\text { mine soil + lime1 }\left(25 \mathrm{tha}^{-1}\right)+\text { phosphate fertilizer }\left(300 \mathrm{~kg} \mathrm{ha}^{-1}\right) \\
\text { mine soil }+ \text { lime1 }(25 \mathrm{tha})+\text { River sediment }(30 \%, \mathrm{w}: \mathrm{w}) \\
\text { mine soil + lime1 }\left(25 \mathrm{t} \mathrm{ha}^{-1}\right)+\text { NPK compound fertilizer }\left(150 \mathrm{~kg} \mathrm{ha}^{-1}\right)+ \\
\text { River sediment }(30 \%, \mathrm{w}: \mathrm{w})\end{array}$ \\
\hline
\end{tabular}


Table 2. Cont.

\begin{tabular}{|c|c|c|}
\hline $\begin{array}{l}\text { Treatment } \\
\text { types }\end{array}$ & Treatments & Amendments \\
\hline \multirow{5}{*}{ L2 } & lime2 & mine soil + lime2 $\left(50 \mathrm{t} \mathrm{ha}^{-1}\right)$ \\
\hline & lime2+NPK & mine soil + lime2 $\left(50 \mathrm{tha}^{-1}\right)+$ NPK compound fertilizer $\left(150 \mathrm{~kg} \mathrm{ha}^{-1}\right)$ \\
\hline & lime2+P & mine soil + lime2 $\left(50 \mathrm{t} \mathrm{ha}^{-1}\right)+$ phosphate fertilizer $\left(300 \mathrm{~kg} \mathrm{ha}^{-1}\right)$ \\
\hline & lime2+Rs & mine soil + lime2 $\left(50 \mathrm{t} \mathrm{ha}^{-1}\right)+$ River sediment $(30 \%, \mathrm{w}: \mathrm{w})$ \\
\hline & lime2+NPK+Rs & $\begin{array}{c}\text { mine soil + lime2 }\left(50 \mathrm{t} \mathrm{ha}^{-1}\right)+\text { NPK compound fertilizer }\left(150 \mathrm{~kg} \mathrm{ha}^{-1}\right)+ \\
\text { River sediment }(30 \%, \mathrm{w}: \mathrm{w})\end{array}$ \\
\hline
\end{tabular}

* Sawdust was added to all the treatments, except for control1.

\subsection{DNA Extraction, 16S rRNA Polymerase Chain Reaction (PCR) and Bacterial Community T-Restriction Fragment Length Polymorphism (RFLP) Profiles Analysis}

Genomic DNA was extracted using a modification of the protocol described by Tan et al. [19]. In brief, $5 \mathrm{~g}$ soil was added to $10 \mathrm{~mL}$ of buffer [100 mM Tris- $\mathrm{HCl}(\mathrm{pH} 8.0), 100 \mathrm{mM}$ ethylene diamine tetraacetic acid (EDTA) ( $\mathrm{pH} 8.3), 100 \mathrm{mM}$ phosphate buffer ( $\mathrm{pH} 8.0), 1.5 \mathrm{M} \mathrm{NaCl}$, $1 \%$ cetyltrimethylammonium bromide], $50 \mu \mathrm{L}$ of proteinase $\mathrm{K}\left(20 \mathrm{mg} \mathrm{mL}^{-1}\right)$ and $60 \mu \mathrm{L}$ of lysozyme $\left(100 \mathrm{mg} \mathrm{mL}^{-1}\right)$. Samples were incubated at $37^{\circ} \mathrm{C}$ with shaking at $250 \mathrm{rpm}$ for $30 \mathrm{~min} .1 .5 \mathrm{~mL}$ of $20 \%$ sodium dodecyl sulphate was added, and the tubes were gently agitated and then incubated at $65^{\circ} \mathrm{C}$ for $2 \mathrm{~h}$. Samples were centrifuged at $10000 \mathrm{xg}$ for $10 \mathrm{~min}$. The supernatant was extracted with phenol-chloroform-isoamyl alcohol (25:24:1) and chloroform-isoamly alcohol (24:1). DNA was precipitated with 0.6 volumes of isopropanol, washed with $1 \mathrm{~mL}$ of $70 \%$ ethanol and resuspended in sterile, deionized water. The quantity of the DNA extracted was checked with a spectrophotometer (NanoDrop).

16S rRNA gene fragments were amplified from the bulk DNA sample using the universal primers 533F (5'-GTGCCAGCMGCCGCGGTAA-3') and 1492R (5'-GGTTACCTTGTTACGACT T-3') [20]. PCR reactions were performed in $40 \mu \mathrm{L}$ aliquots containing $20 \mu \mathrm{L}$ of Mix (0.1 U Taq DNA polymerase $\mu \mathrm{L}^{-1}, 500 \mu \mathrm{M}$ dNTP each, $20 \mathrm{mM}$ Tris- $\mathrm{HCl}(\mathrm{pH}$ 8.0), $100 \mathrm{Mm} \mathrm{KCl}, 3 \mathrm{mM} \mathrm{MgCl}$, obtained from Beijing Tiangen Bio-Engineering and Technologies, China), $0.4 \mu \mathrm{L}$ of each primer, $18.2 \mu \mathrm{L}$ of $\mathrm{dH}_{2} \mathrm{O}$ and $10 \mathrm{ng}$ extracted total soil DNA. The thermocycling conditions were as follows: a hot start at $94{ }^{\circ} \mathrm{C}$ for $4 \mathrm{~min}$ ( 1 cycle), $94^{\circ} \mathrm{C}$ for $1 \mathrm{~min}, 55^{\circ} \mathrm{C}$ for $1 \mathrm{~min}, 72^{\circ} \mathrm{C}$ for $2 \mathrm{~min}$ ( 35 cycles), and a final extension at $72{ }^{\circ} \mathrm{C}$ for $10 \mathrm{~min}$. PCR products were first visualized on a $1 \%$ agarose gel and purified using a High Pure PCR Product Clean Up Kit (Roche Diagnostics GmbH, Penzberg, Germany) according to the manufacturer's instructions.

The purified PCR products were digested enzymatically as follows: approximately $10 \mu \mathrm{L}$ of PCR product was added to a reaction mixture containing sterile Millipore water, $30 \mathrm{U}$ of restriction endonuclease Msp I / Rsa I and $2 \mu \mathrm{L}$ of corresponding enzyme buffer. Digests were performed in a final volume of $20 \mu \mathrm{L}$, incubated in a water bath at $37^{\circ} \mathrm{C}$ for $4-6 \mathrm{~h}$ and denatured $65^{\circ} \mathrm{C}$ for $20 \mathrm{~min}$. Terminal restriction fragments (T-RFs) were determined by electrophoresis using a ABI3730 automated sequencer (USA), and analysis of fragment profiles was performed using Peak-Scanner Software v.1.0. Only fragments with a fluorescence $>1 \%$ of the total fluorescence were included in the analyses.

Bacterial community structure was estimated using the Shannon-Wiener diversity index $(\mathrm{H})$ which was calculated as described by De Leij et al. [21] using the following formula:

$$
H=-\sum_{i=1}^{n}\left(P_{i} \ln P_{i}\right)
$$

where $\mathrm{p}_{\mathrm{i}}$ is the relative abundance of each T-RF in the total sum and $\mathrm{n}$ is the number of detected T-RFs. 


\subsection{Microbial Activity and Microbial Biomass carbon Analysis}

Basal soil respiration was used as a measure of microbial activity and was determined according to the method of Anderson [22]. Briefly, $30 \mathrm{~g}$ fresh soil was incubated in an air-tight sealed jar at $25^{\circ} \mathrm{C}$ for $24 \mathrm{~h}$ in the dark. $\mathrm{CO}_{2}$ produced during the test was absorbed in $0.05 \mathrm{M} \mathrm{NaOH}$ and quantified by titration with $0.1 \mathrm{M} \mathrm{HCl}$. Soil microbial biomass $\mathrm{C}$ was determined based on a modification of the chloroform fumigation extraction method of Vance et al. [23]. In brief, $10 \mathrm{~g}$ fresh soil was fumigated with chloroform for 7 days and extracted for $1 \mathrm{~h}$ in $50 \mathrm{~mL} \mathrm{~K} \mathrm{SO}_{4}$. Organic $\mathrm{C}$ in the extracts was oxidized by dichromate and titration with $\mathrm{FeSO}_{4}$. Microbial biomass $\mathrm{C}$ was calculated as the difference between fumigated and non-fumigated samples and corrected with a $K_{\mathrm{EC}}$ value of 0.38 .

\subsection{Soil Enzyme Activities Analysis}

Dehydrogenase activity was measured according to the method of Thalmann [24]. $5 \mathrm{~g}$ fresh soil was added to $5 \mathrm{~mL} 0.5 \%$ tryphenyltetrazolium chloride (TTC, $\mathrm{pH} 7.4$ ) and incubated in darkness for $16 \mathrm{~h}$ at $25^{\circ} \mathrm{C}$. After incubation, the triphenylformazan (TPF) produced was extracted with acetone and measured spectrometrically at $546 \mathrm{~nm}$. Dehydrogenase activity was expressed in $\mu \mathrm{g}$ TPF g ${ }^{-1}$. Cellulase activity was determined by the method of Schinner and von Mersi [25]. $10 \mathrm{~g}$ fresh soil was added to $15 \mathrm{~mL} 2 \mathrm{M}$ substrate solution and acetate buffer ( $\mathrm{pH}$ 5.5) and incubated for $24 \mathrm{~h}$ at $50{ }^{\circ} \mathrm{C}$. After incubation, the glucose (GE) released was extracted with reagent $\left[\mathrm{NH}_{4} \mathrm{Fe}\left(\mathrm{SO}_{4}\right)_{2} \cdot 12 \mathrm{H}_{2} \mathrm{O}+\mathrm{SDS}\right]$ and measured spectrometrically at $690 \mathrm{~nm}$. Cellulase activity was expressed in $\mu \mathrm{g} \mathrm{GE} \mathrm{g}^{-1}$. Urease activity was assayed using the method of Kandeler and Gerber [26]. $5 \mathrm{~g}$ fresh soil was added to $2.5 \mathrm{~mL}$ $0.72 \mathrm{M}$ urea solution and $20 \mathrm{~mL} 0.1 \mathrm{M}$ borate buffer $(\mathrm{pH} 10)$ and incubated for $2 \mathrm{~h}$ at $37^{\circ} \mathrm{C}$. After incubation, the ammonia released was extracted with sodium dichloro isocyanurate and measured spectrometrically at $625 \mathrm{~nm}$. Urease activity was expressed in $\mu \mathrm{g} \mathrm{NH}_{4}{ }^{+}-\mathrm{N} \mathrm{g}^{-1}$. Acid phosphatase activity was measured following the method of Tabatabai and Bremner [27]. $1 \mathrm{~g}$ fresh soil was incubated in acid phosphate solution for $1 \mathrm{~h}$ at $37^{\circ} \mathrm{C}$. After incubation, the produced p-nitrophenyl (PNP) was extracted with sodium hydroxide and measured spectrometrically at $400 \mathrm{~nm}$. Acid phosphatase activity was expressed in $\mu \mathrm{g}$ PNP g ${ }^{-1}$.

\subsection{Soil Nutrients Analysis}

Soil $\mathrm{pH}$ was measured in a 1:2.5 (w/v) aqueous suspension using a pH meter (CyberScan $\mathrm{pH}$ 510, Oakton, USA). Soil organic matter (OM) was determined by dichromate oxidation and titration with ferrous ammonium sulphate [28]. Total nitrogen (TN) was measured by a semi-micro Kjeldahl method [29]. Ammonium nitrogen $\left(\mathrm{NH}_{4}{ }^{+}-\mathrm{N}\right)$ was extracted with potassium chloride and analyzed by indophenol blue colorimetry [30]. Nitrate-nitrogen $\left(\mathrm{NO}_{3}{ }^{-}-\mathrm{N}\right)$ was extracted with calcium sulphate and analyzed following phenol disulphonic acid colorimetry [31]. Total (TP) and available phosphorus (AP) were analyzed by the molybdenum blue method after digestion with concentrated sulphuric acid and extraction with sodium bicarbonate [32]. Total potassium (TK) and available potassium (AK) were determined by inductively-coupled optical emission spectrometry (ICP-OES, iCAP6300, Thermo Electron, Waltham, MA, USA) after digestion with aqua regia in a microwave digester (MARS 5, CEM Corporation, Matthews, NC, USA) and extraction with ammonium acetate [33].

\subsection{Statistical Analysis}

Statistical analyses were conducted using the SPSS statistical package (version 19.0, SPSS, Chicago, IL, USA). Differences between the treatments in microbial diversity, biomass C, enzyme activities and soil nutrients were tested after one-way analysis of variance of the data sets. The least significant difference (LSD) test was used to identify the significance of any differences between means. The samples with similar behaviour and the key parameters describing data variability were recognized by conducting a principal components analysis (PCA) [34]. The relationships between soil microbial 
community properties and nutrient parameters were explored using canonical correspondence analysis (CCA: Canoco 4.5 for Windows, ter Braak and Šamilauer [35]).

\section{Results}

\subsection{Effects of the Amendments on Microbial Diversity, Community Structure and Function}

Soil microbial diversity, activity and biomass $C$ were low in control 1 and control2, and the addition of the amendments significantly $(p<0.05)$ increased both microbial activity and biomass $C$, by comparison with the controls (Figure 1). However, few significant differences were observed between L1 and L2 treatments in either microbial activity or biomass $C(p>0.05)$. Compared to the controls, soil microbial diversity significantly increased in the treatments with river sediment (lime1 + Rs, lime1 + NPK + Rs, lime2 + Rs, lime2 + NPK + Rs). No significant differences were observed between the treatments without river sediment and the two controls. Moreover, there were few significant differences in microbial diversity between the L1 and L2 treatments $(p>0.05)$. In addition, remarkable differences in microbial community structure between treatments were observed (Figure S2).
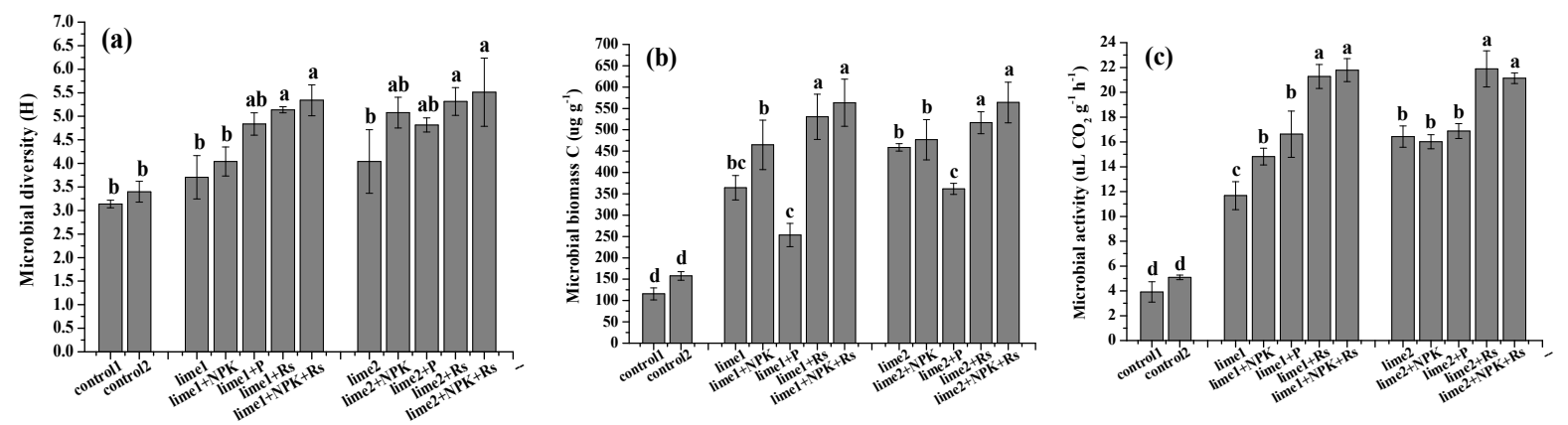

Figure 1. Soil microbial diversity, biomass $C$ and activity in the mine soil with different amendments (means \pm S.E., $\mathrm{n}=4$ ). The bars with different letters indicated significant differences at $p<0.05$ according to LSD test. lime1 $\left(25 \mathrm{t} \mathrm{ha}^{-1}\right)$, lime2 $\left(50 \mathrm{t} \mathrm{ha}^{-1}\right)$, Rs (river sediment $30 \%$, w:w); (a) Soil microbial diversity; (b): Soil microbial biomass C (c): Soil microbial activity

\subsection{Effects of the Amendments on Soil Enzyme Activity}

The soil enzyme activities in the mine soil with different amendments are shown in Figure 2. The two controls mostly showed very low mean values for dehydrogenase, cellulase and urease activities and the added amendments significantly $(p<0.05)$ enhanced cellulase and urease activities relative to control1 and control2. Compared to the controls, dehydrogenase activity increased only in lime1 + Rs, lime1 + NPK + Rs, lime2 + NPK, lime2 + Rs and lime2 + NPK + Rs treatments $(p<0.05)$. In contrast, the highest value of acid phosphatase activity was observed in the controls and its activity reduced after the application of the amendments when compared to the controls.
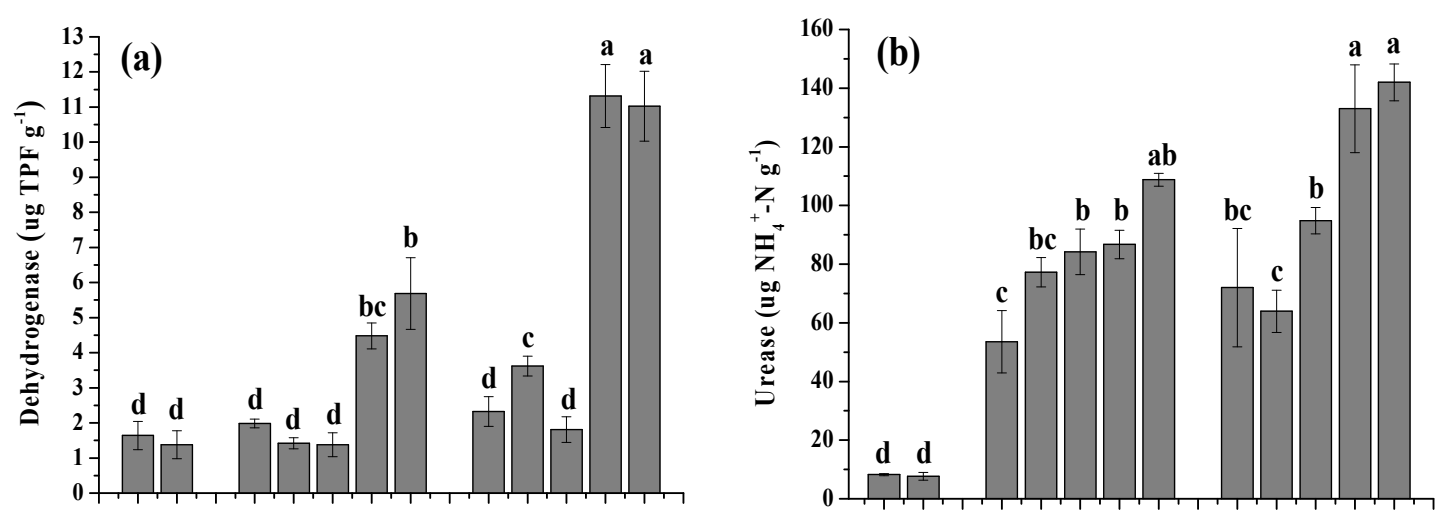

Figure 2. Cont. 

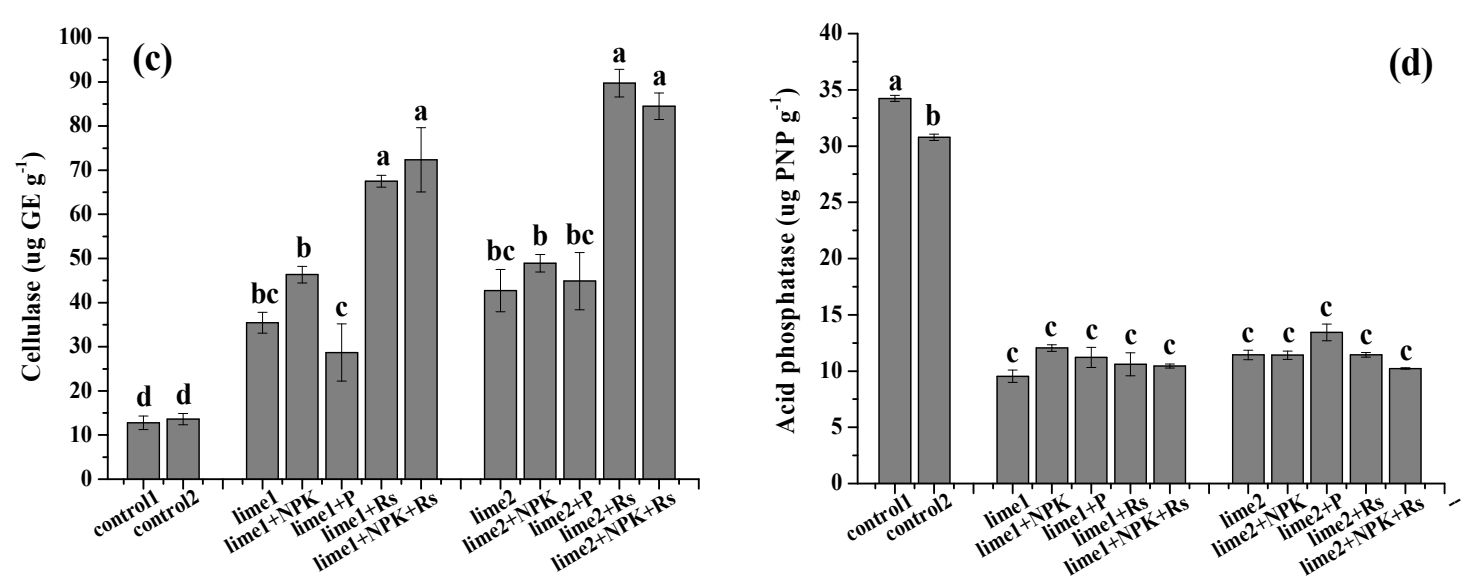

Figure 2. Soil enzyme activities in the mine soil with different amendments (means \pm S.E, $\mathrm{n}=4$ ). The bars with different letters indicated significant differences at $p<0.05$ according to LSD test. lime1 (25 $\mathrm{t} \mathrm{ha}^{-1}$ ), lime2 (50 tha $\left.{ }^{-1}\right)$, Rs (river sediment 30\%, w:w); (a): dehydrogenase activity; (b): urease activity; (c): cellulase activity; (d): acid phosphatase activity

\subsection{Effects of the Amendments on Soil Nutrient Elements}

Table 3 presents the major nutrients measured in the different treatments. In all cases, the mine soil (control1) showed very low mean values for organic matter $(\mathrm{OM})$ and the major nutrient elements $(\mathrm{N}, \mathrm{P}$ and $\mathrm{K})$. The added amendments significantly $(p<0.05)$ increased the values of $\mathrm{OM}, \mathrm{TN}, \mathrm{NH}_{4}{ }^{+}-\mathrm{N}$, $\mathrm{NO}_{3}{ }^{-}-\mathrm{N}, \mathrm{TP}, \mathrm{AP}, \mathrm{TK}$ and $\mathrm{AK}$ than those in control1, respectively. There were few significant differences between L1 and L2 treatments in altering soil nutrient characteristics. In addition, control2 had greater values of nutrient concentrations than did control1 due to the sawdust application.

Table 3. Nutrient elements in the mine soil with different amendments (means \pm S.E., $n=4$ ).

\begin{tabular}{cccc}
\hline OM $\left(\mathbf{g ~ k g}^{\mathbf{- 1}}\right)$ & TN $\left(\mathbf{m g ~ k g}^{-\mathbf{1}}\right)$ & $\mathbf{T P}\left(\mathbf{m g ~ k g}^{\mathbf{- 1}}\right)$ & TK $\left.\mathbf{~} \mathbf{m g ~ k g}^{\mathbf{- 1}}\right)$ \\
\hline $3.7 \pm 0.93 \mathrm{c}$ & $72 \pm 3.6 \mathrm{~d}$ & $276 \pm 2.9 \mathrm{~d}$ & $183 \pm 2.7 \mathrm{~d}$ \\
$21 \pm 2.4 \mathrm{~b}$ & $179 \pm 8.8 \mathrm{c}$ & $289 \pm 8.2 \mathrm{~d}$ & $229 \pm 26 \mathrm{~d}$ \\
$21 \pm 0.76 \mathrm{~b}$ & $235 \pm 7.9 \mathrm{~b}$ & $297 \pm 10 \mathrm{~d}$ & $286 \pm 24 \mathrm{~d}$ \\
$23 \pm 1.5 \mathrm{~b}$ & $236 \pm 7.5 \mathrm{~b}$ & $303 \pm 11 \mathrm{~d}$ & $289 \pm 27 \mathrm{~d}$ \\
$23 \pm 1.4 \mathrm{~b}$ & $232 \pm 6.2 \mathrm{~b}$ & $359 \pm 11 \mathrm{c}$ & $386 \pm 28 \mathrm{c}$ \\
$25 \pm 0.59 \mathrm{ab}$ & $458 \pm 12 \mathrm{a}$ & $446 \pm 10 \mathrm{~b}$ & $551 \pm 44 \mathrm{ab}$ \\
$25 \pm 1.7 \mathrm{ab}$ & $487 \pm 35 \mathrm{a}$ & $423 \pm 14 \mathrm{~b}$ & $630 \pm 52 \mathrm{a}$ \\
$23 \pm 0.66 \mathrm{~b}$ & $221 \pm 10 \mathrm{~b}$ & $322 \pm 11 \mathrm{~cd}$ & $266 \pm 7.3 \mathrm{~d}$ \\
$27 \pm 1.4 \mathrm{a}$ & $237 \pm 6.3 \mathrm{~b}$ & $326 \pm 5.3 \mathrm{~cd}$ & $262 \pm 6.2 \mathrm{~d}$ \\
$27 \pm 1.5 \mathrm{a}$ & $262 \pm 4.3 \mathrm{~b}$ & $362 \pm 18 \mathrm{c}$ & $410 \pm 41 \mathrm{c}$ \\
$28 \pm 2.0 \mathrm{a}$ & $478 \pm 5.3 \mathrm{a}$ & $418 \pm 8.0 \mathrm{~b}$ & $525 \pm 14 \mathrm{~b}$ \\
$29 \pm 1.8 \mathrm{a}$ & $492 \pm 14 \mathrm{a}$ & $513 \pm 23 \mathrm{a}$ & $521 \pm 24 \mathrm{~b}$ \\
\hline
\end{tabular}

* Different letters in the same column indicated significant differences at $p<0.05$ according to LSD test.

\subsection{Evaluation of the Differences and Similarities of Amendment Effects using PCA}

Figure $3 a$ presents the plot of the different amendments with the first two principal components (PCs) of the PCA results obtained from soil microbial community variables. The cumulative $\%$ of the first two PCs was $80.1 \%$, with PC1 $68.5 \%$ and PC2 $11.6 \%$ of the total variance. Microbial activity, microbial biomass $\mathrm{C}$, dehydrogenase, cellulase and urease activities had large positive loading coefficients on PC1 (loading > 0.7), while acid phosphatase had a large negative loading on PC1. The amended samples almost all located on the positive side of $\mathrm{PC} 1$, indicating higher microbial activity, microbial biomass $\mathrm{C}$, dehydrogenase, cellulase and urease and lower acid phosphatase activities. In contrast, the control1 and control2 samples were positioned on the negative side of PC1, suggesting higher acid phosphatase and lower microbial activity, microbial biomass $C$, dehydrogenase, cellulase and 
urease activities. The treatments with and without river sediment were also separated, suggesting that the combination of lime and river sediment had a greater effectiveness compared to the other treatments. As to the PCA for soil nutrient elements, the value of $\mathrm{PC} 1$ was $71.2 \%$ of the total variance and $\mathrm{PC} 2$ was $12.1 \%$ (Figure $3 \mathrm{~b}$ ). $\mathrm{TN}, \mathrm{NH}_{4}{ }^{+}-\mathrm{N}, \mathrm{NO}_{3}{ }^{-}-\mathrm{N}, \mathrm{TP}, \mathrm{AP}$ and $\mathrm{TK}$ had large loading coefficients on PC1, all with positive values. The treatments with river sediment (lime1 + Rs, lime1 + NPK + Rs, lime $2+$ Rs, lime $2+$ NPK + Rs) are located on the right section of PC1; the treatments without river sediment (lime1, lime1 + NPK, lime1 + P, lime2, lime2 + NPK, lime2 + P) are in the central part of the diagram, whereas the two controls are positioned to the left. A separation between control1 and control2 is again attributed to the sawdust addition.
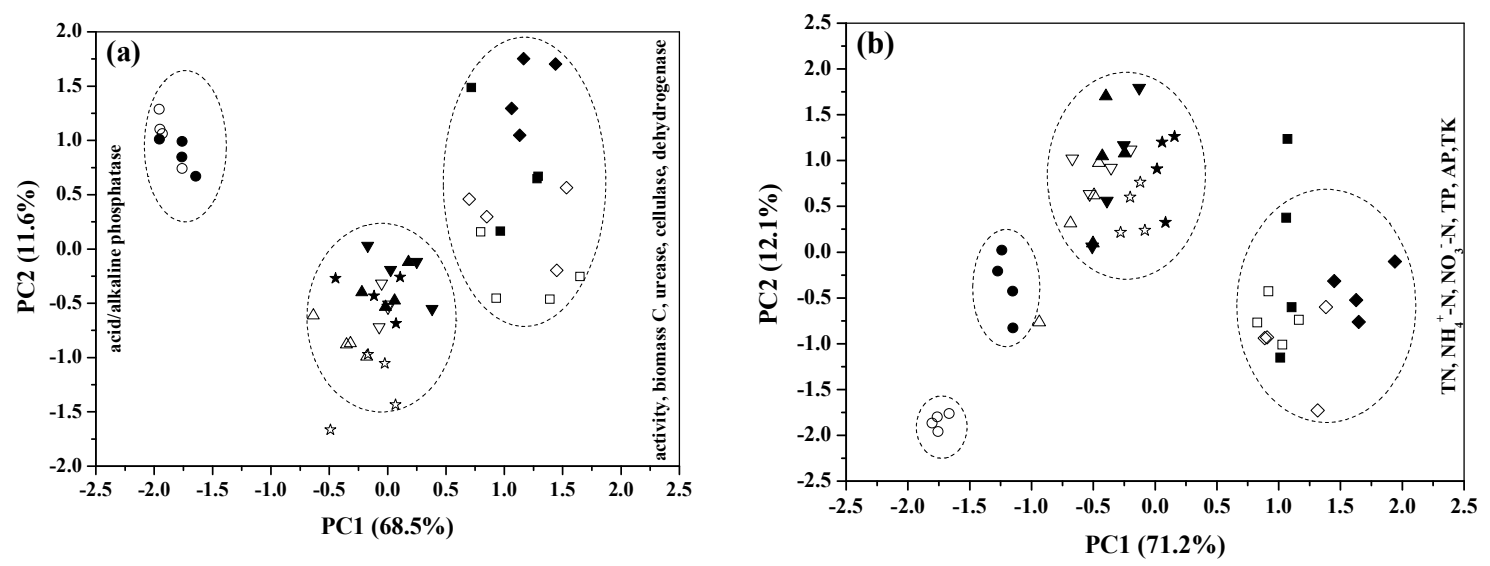

Figure 3. Bioplot of the principal components on soil nutrient and microbial properties $(n=48)$. (a) Microbial properties, (b) Nutrient profiles. PC1: the first principal component; PC2: the second principal component. The most important parameters for the definition of the two components are shown on the edge of each axis, indicating the direction in which the value of the parameter increases.

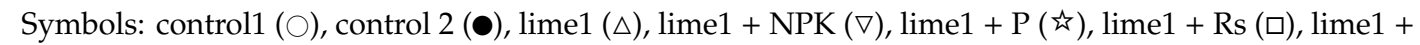
NPK + Rs $(\diamond)$, lime2 $(\boldsymbol{\Delta})$, lime2 + NPK $(\mathbf{v})$, lime2 + P $(\star)$, lime2 + Rs $(\boldsymbol{\bullet})$, lime2 + NPK + Rs $(\diamond)$.

\subsection{Relationships between Soil Microbial Properties and Nutrient Parameters}

CCA was carried out to determine how soil nutrient parameters influenced microbial community properties. The results (Table S1 and Figure 4) revealed that a big (cumulative sum of $92.2 \%$ for Axes 1 and 2$)$ and a significant $(p=0.002)$ percentage of the overall variance in environmental factors and microbial data (Monte-Cario significant test). The cumulative species-environment relation for both axes was $95.5 \%$ and species-environment correlations for both axes were 0.82 and 0.58 , indicating a strong correlation between microbial profiles and soil nutrient parameters. On the diagram, soil nutrient variables were represented by arrows and microbial variables are shown as triangles. The length of a given arrow indicates the relative importance of a specific soil nutrient factor represented by the arrow in explaining variation in the microbial properties and the angle between a given arrow and a triangle indicates the degree to which they are correlated. Microbial diversity, activity, biomass $C$, dehydrogenase, cellulase and urease activities were in the same direction as the arrows for all the nutrients which indicates that they are positively correlated with these nutrient elements. Acid phosphatase is in the opposite direction to the nutrients, indicating a negative correlation between acid phosphatase activity and the nutrient elements.

\section{Discussion}

Soil microorganisms play a key role in many soil processes and the delivery of essential soil ecosystem services. The development of microbial diversity is crucial to facilitate a sustainable ecosystem in post-mining soils $[6,18]$. In this study, the overall microbial diversity was low and only the treatments with river sediment (lime1 + Rs, lime1 + NPK + Rs, lime2 + Rs, lime2 + NPK + 
Rs) significantly increased microbial diversity relative to the controls (Figure 1a). In river sediment, organic matter-decomposing Escherichia, nitrogen-metabolizing Nitrosopumilus and sulphate-reducing Desulfococcus genera were reported to be abundant and their abundance were found to be statistically associated with the redox state of soil and $\mathrm{C}$ and $\mathrm{N}$ turnover [36]. Therefore, the addition of river sediment cannot only ameliorate the mine soil physic-chemical conditions (Table 1), but also speed up the shift of soil microbial community (Figure 1a). It was argued in the literature that driving factors for the evolution of a microbial community structure largely depend on the environmental gradient to which the communities are subjected or imposed under experimentally [16]. Organic $\mathrm{C}$, $\mathrm{N}$ availability, $\mathrm{pH}$, salinity and many other abiotic factors influence the microbial community in soil [37-39]. A similar result was also reported by Li et al. [9] who found that the addition of native soil to $\mathrm{Cu}-\mathrm{Pb}-\mathrm{Zn}$ tailings significantly changed the composition and structure of microbial communities. Therefore, incorporation of amendments may fast-track the establishment of microbial community and initiate the rehabilitation of biogeochemical process of mine soils [2,9].

In addition, soil microbial activity and biomass all vary with different types of remediation. In this study, the added amendments significantly increased microbial activity and microbial biomass $C$ (Figure 1). This is in accordance with the findings of Zornoza et al. [40], who employed calcium carbonate and pig slurry manure as amendments to restore a bare acidic tailings pond. These authors found that the amendments increased $\mathrm{pH}$ up to neutrality and significantly enhanced both soil microbial biomass and activity. The explanation for their results was that the amendments ameliorated soil conditions such as $\mathrm{pH}$, metal availability, organic matter and nutrient status, all of which impact on ecosystem function [40]. In our study, the application of amendments successfully reduced acidity and heavy metal availability (see Yang et al., [17] for details) and increased the values of $\mathrm{OM}, \mathrm{TN}, \mathrm{TP}, \mathrm{TK}, \mathrm{NH}_{4}{ }^{+}-\mathrm{N}$, $\mathrm{NO}_{3}{ }^{-}-\mathrm{N}, \mathrm{AP}$ and $\mathrm{AK}$ (Table 3). A suitable $\mathrm{pH}$, low heavy metal toxicity and enhancement of nutrient status after remediation were the most determining factors for soil microbial community responses. Soil enzymes play a fundamental role in nutrient mineralization, organic matter decomposition and nutrient cycling and their activities have increasingly been used to evaluate the success of remediation efforts [14]. In the present study, the application of amendments significantly increased dehydrogenase, cellulase and urease activities (Figure 2), probably attributable to neutralization and amelioration by lime, river sediment and NPK fertilization or phosphate alone. This is in accordance with the results of Li et al. [6], who found soil $\mathrm{pH}$ and improved soil conditions were the primary regulators of soil microbial communities and enzyme activities. The role of amendments in improving nutrient status was further corroborated by the CCA which suggested that there were significant positive correlations between dehydrogenase, cellulase, urease activities and nutrient elements (Figure 4). In contrast, the circum-neutral environment after the application of amendments (see Yang et al., [17] for details) was not optimal for acid phosphatase activity which was significantly decreased by comparison with the controls (Figure 2). This is consistent with the significant negative correlation detected between acid phosphatase activity and nutrient element status (Figure 4).

It is well known that microbial community is an essential player in soil functioning and biogeochemical cycling in mine soils. The application of amendments can accelerate soil-forming processes, develop microbial communities and initiate nutrient cycling [41]. Different amendments and/or combinations of these differed in their effectiveness on improving the soil physico-chemical properties and the microbial community. In this present study, three separate clusters [two controls, the treatments without river sediment (lime1, lime1 + NPK, lime1 + P, lime2, lime2 + NPK, lime $2+\mathrm{P})$ and the treatments with river sediment (lime1 + RS, lime1 + NPK + Rs, lime2 + Rs, lime $2+$ NPK + Rs)] were observed according to the PCA loadings of microbial activity, biomass C, dehydrogenase, cellulase and urease activities (Figure 3a). For the PCA obtained for soil nutrient elements, four clusters separated which included control1, control2, the treatments without river sediment (lime1, lime1 + NPK, lime1 + P, lime2, lime2 + NPK, lime2 + P) and the treatments with river sediment (lime1 + Rs, lime1 + NPK + Rs, lime2 + Rs, lime2 + NPK + Rs) (Figure 3b). Collectively, the treatments with river sediment (lime1 + Rs, lime1 + NPK + Rs, lime2 + Rs, lime2 + NPK + Rs) were 
efficient and sufficient in improving the soil microbial community and nutrient status. Economically, the treatment lime $1+$ Rs (i.e., the combined use of $25 \mathrm{tha}^{-1}$ lime and river sediment (30\%)) will be the preferred option for full remediation of these mine soils.

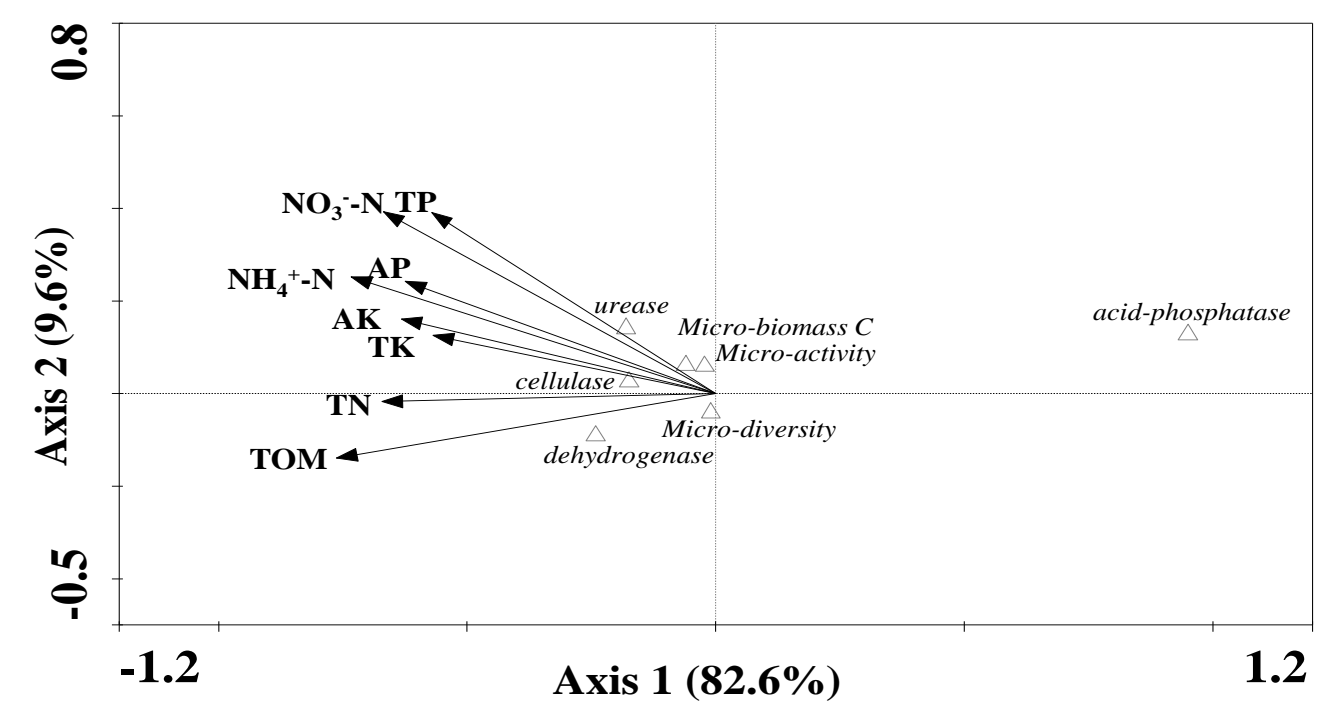

Figure 4. Canonical correspondence analysis (CCA) ordination diagram of microbial parameters with soil nutrient factors. The soil nutrient factors are represented as arrows and microbial parameters are shown as triangles.

\section{Conclusions}

The results obtained in this study suggest that the application of lime, NPK compound fertilizer, phosphate fertilizer and river sediment were all efficient in improving the soil microbial diversity, biomass, enzyme activities and nutrient status of an extremely acidic metalliferous mine soil. Soil microbial diversity, activity and biomass $C$ were positively correlated with soil nutrient elements, which suggested these factors are likely to be synergistic in the remediation of the mine soil. Furthermore, our results indicate that the treatment lime1 $\left(25 \mathrm{t} \mathrm{ha}^{-1}\right)+\mathrm{Rs}(30 \%)$ will be a more economic and practical option.

Supplementary Materials: Supplementary materials are available online at http://www.mdpi.com/2076-3417/9/8/ 1552/s1. Figure S1: A photo showing the pot experiment. Figure S2: Bacterial community profiles based on T-RFs of the 16S DNA gene digested with Rsa I and Msp I. Lanes 1-12 stand for 12 treatments with double lanes per treatment. Lane 1: control1, Lane 2: control 2, Lane 3: lime1, Lane 4: lime1 + NPK, Lane 5: lime1 + P, Lane 6: lime1 + Rs, Lane 7: lime1 + NPK + Rs, Lane 8: lime2, Lane 9: lime2 + NPK, Lane 10: lime2 + P, Lane 11: lime2 + Rs, Lane 12: lime2 + NPK + Rs., Table S1: Results of canonical correspondence analysis (CCA).

Author Contributions: J.L., S.Y. and R.X. conceived the research questions. S.Y. conducted the experiment, and B.L. helped with data collection. S.Y. wrote an original draft, R.X. and J.L. revised the paper.

Funding: This work was supported by the National Natural Science Foundation of China (Nos. 41561076 \& 41622106), the Guizhou Natural Science Foundation (Qian Jiao He Jichu [2019]1322), Science and Technology Top-notch Talent Project of Guizhou Province (Qian Jiao He KYzi [2018]065), Project of Key Laboratory of Soil Resources and Environment in Qianbei of Guizhou Province (Qian Jiao He KYzi [2017]010) and the Doctor Start Project of Zunyi Normal University (Zun Shi BS[2017]13). We thank Professor Alan Baker (The Universities of Melbourne and Queensland, Australia) for improvement of the text of this paper.

Conflicts of Interest: The authors declare no conflict of interest.

\section{References}

1. Karaca, O.; Cameselle, C.; Reddy, K.R. Mine tailings disposal sites: Contamination problems, remedial options and phytocaps for sustainable remediation. Rev. Environ. Sci. Biol. 2018, 17, 205-228. [CrossRef]

2. Li, Y.; Jia, Z.; Sun, Q.; Zhan, J.; Yang, Y.; Wang, D. Ecological restoration alters microbial communities in mine tailings profiles. Sci. Rep. 2016, 6, 25193. [CrossRef] 
3. Wang, L.; Ji, B.; Hu, Y.H.; Liu, R.Q.; Sun, W. A review on in situ phytoremediation of mine tailings. Chemosphere 2017, 184, 594-600. [CrossRef]

4. Kabas, S.; Faz, A.; Acosta, J.A.; Zomoza, R.; Martinez-Martinez, S.; Camona, D.M.; Bech, J. Effect of marble waste and pig slurry on the growth of native vegetation and heavy metal mobility in a mine tailing pond. J. Geochem. Explor. 2012, 123, 69-76. [CrossRef]

5. Pardo, T.; Bernal, M.P.; Clemente, R. Efficiency of soil organic and inorganic amendments on the remediation of a contaminated mine soil: I. Effects on trace elements and nutrients solubility and leaching risk. Chemosphere 2014, 107, 121-128. [CrossRef]

6. Li, J.J.; Zhou, X.M.; Yan, J.X.; Li, H.J.; He, J.Z. Effects of regenerating vegetation on soil enzyme activity and microbial structure in reclaimed soils on a surface coal mine site. Appl. Soil Ecol. 2015, 87, 56-62. [CrossRef]

7. Thavamani, P.; Samkumar, R.A.; Satheesh, V.; Subashchandrabose, S.R.; Ramadass, K.; Naidu, R.; Venkateswarlu, K.; Megharaj, M. Microbes from mined sites: Harnessing their potential for reclamation of derelict mine sites. Environ. Pollut. 2017, 230, 495-505. [CrossRef] [PubMed]

8. Zornoza, R.; Acosta, J.A.; Faz, A.; Bååth, E. Microbial growth and community structure in acid mine soils after addition of different amendments for soil reclamation. Geoderma 2016, 272, 64-72. [CrossRef]

9. Li, X.F.; You, F.; Bond, P.L.; Huang, L.B. Establishing microbial diversity and functions in weathered and neutral $\mathrm{Cu}-\mathrm{Pb}-\mathrm{Zn}$ tailings with native soil addition. Geoderma 2015, 247-248, 108-116. [CrossRef]

10. Izquierdo, I.; Caravaca, F.; Alguacil, M.M.; Hernández, G.; Roldán, A. Use of microbiological indicators for evaluating success in soil restoration after revegetation of a mining area under subtropical conditions. Appl. Soil Ecol. 2005, 30, 3-10. [CrossRef]

11. Gil-Sotres, F.; Trasar-Cepeda, C.; Leirós, M.C.; Seoane, S. Different approaches to evaluating soil quality using biochemical properties. Soil Biol. Biochem. 2005, 37, 877-887. [CrossRef]

12. Tejada, M.; Hernandez, M.T.; Garcia, C. Application of two organic amendments on soil restoration: Effects on the soil biological properties. J. Environ. Qual. 2006, 35, 1010-1017. [CrossRef]

13. Alvarenga, P.; Palma, P.; Gonçalves, A.P.; Fernandes, R.M.; de Varennes, A.; Vallini, G.; Duarte, E.; Cunha-Queda, A.C. Organic residues as immobilizing agents in aided phytostabilization: (II) Effects on soil biochemical and ecotoxicological characteristics. Chemosphere 2009, 74, 1301-1308. [CrossRef]

14. Yang, S.X.; Cao, J.B.; Li, F.M.; Peng, X.Z.; Yang, Z.H.; Chai, L.Y. Field evaluation of the effectiveness of three industrial by-products as organic amendments for aided phytostabilization of a $\mathrm{Pb} / \mathrm{Zn}$ mine tailings. Environ. Sci. Proc. Impacts 2016, 18, 95-103. [CrossRef]

15. Finkenbein, P.; Kretschmer, K.; Kulka, K.; Klotz, S.; Heilmeier, H. Soil enzyme activities as bioindicators for substrate quality in revegetation of a subtropical coal mining dump. Soil Biol. Biochem. 2013, 56, 87-89. [CrossRef]

16. Li, X.F.; Bond, P.L.; Van Nostrand, J.D.; Zhou, J.Z.; Huang, L.B. From lithotroph- to organotroph-dominant: Directional shift of microbial community in sulphidic tailings during phytostabilization. Sci. Rep. 2015, 5, 12978. [CrossRef]

17. Yang, S.X.; Li, J.T.; Yang, B.; Liao, B.; Zhang, J.T.; Shu, W.S. Effectiveness of amendments on re-acidification and heavy metal immobilization in an extremely acidic mine soil. J. Environ. Monitor. 2011, 13, 1876-1883. [CrossRef]

18. Yang, T.T.; Liu, J.; Chen, W.C.; Chen, X.; Shu, H.Y.; Jia, P.; Liao, B.; Shu, W.S.; Li, J.T. Changes in microbial community composition following phytostabilization of an extremely acidic $\mathrm{Cu}$ mine tailings. Soil Biol. Biochem. 2017, 114, 52-58. [CrossRef]

19. Tan, G.L.; Shu, W.S.; Hallberg, K.B.; Li, F.; Lan, C.Y.; Huang, L.N. Cultivation-dependent and cultivation-independent characterization of the microbial community in acid mine drainage associated with acidic Pb/Zn mine tailings at Lechang, Guangdong, China. FEMS Microbiol. Ecol. 2007, 59, 118-126. [CrossRef]

20. Dojka, M.A.; Hugenholtz, P.; Haack, S.K.; Pace, N.R. Microbial diversity in a hydrocarbon- and chlorinated-solvent-contaminated aquifer undergoing intrinsic bioremediation. Appl. Environ. Microbiol. 1998, 64, 3869-3877.

21. De Leij, F.A.A.M.; Whipps, J.M.; Lynch, J.M. The use of colony development for the characterization of bacterial communities in soil and roots. Microb. Ecol. 1993, 27, 81-97. [CrossRef]

22. Anderson, J.P.E. Soil respiration. In Methods of Soil Analysis, Part 2. Chemical and Microbiological Properties; Soil Science Society of America: Madison, WI, USA, 1982. 
23. Vance, E.D.; Brookes, P.C.; Jenkinson, D.S. An extraction method for measuring soil microbial biomass C. Soil Biol. Biochem. 1987, 19, 703-707. [CrossRef]

24. Thalmann, A. Zur Methodik der Bestimmung der Dehydrogenaseaktivität im Boden mittels Triphenyltetrazoliumchlorid (TTC). Landwirt. Forsch. 1968, 21, 249-258.

25. Schinner, F.; von Mersi, W. Xylanase-, CM-cellulase and invertase activity in soil, an improved method. Soil Biol. Biochem. 1990, 22, 511-515. [CrossRef]

26. Kandeler, E.; Gerber, H. Short-term assay of soil urease activity using colorimetric determination of ammonium. Biol. Fert. Soils 1988, 6, 68-72. [CrossRef]

27. Tabatabai, A.M.; Bremner, M.J. Use of p-nitrophenyl phosphate for assay of soil phosphatase activity. Soil Biol. Biochem. 1969, 1, 301-307. [CrossRef]

28. Nelson, D.W.; Sommers, L.E. Total carbon, organic carbon and organic matter. In Methods of Soil Analysis: Part 2, Agronomy Monograph, 2nd ed.; Page, A.L., Ed.; American Society of Agronomy and Soil Science Society of America: Madison, WI, USA, 1982; Volume 9.

29. Bremner, J.M.; Mulvaney, C.S. Total nitrogen. In Methods of Soil Analysis: Part 2, Agronomy Monograph, 2nd ed.; Page, A.L., Ed.; American Society of Agronomy and Soil Science Society of America: Madison, WI, USA, 1982; Volume 9.

30. Maynard, D.G.; Kalra, Y.P.; Crumbaugh, J.A. Nitrate and Exchangeable Ammonium Nitrogen in Soil Sampling and Methods of Analysis, 2nd ed.; CRC Press, Taylor and Francis: Boca Raton, FL, USA, 2008.

31. Keeney, D.R.; Nelson, D.W. Nitrogen: Inorganic forms. In Methods of Soil Analysis: Part 2, Agronomy Monograph, 2nd ed.; Page, A.L., Ed.; American Society of Agronomy and Soil Science Society of America: Madison, WI, USA, 1982; Volume 9.

32. Bray, R.H.; Kurtz, L.T. Determination of total, organic and available forms of phosphorus in soil. Soil Sci. 1945, 59, 39-45. [CrossRef]

33. Lu, R.S. Soil Agricultural Chemistry Analysis; China Agricultural Technology Press: Beijing, China, 1999.

34. Abollino, O.; Aceto, M.; Malandrino, M.; Mentasti, E.; Sarzanini, C. Heavy metals in agricultural soils from Piedmont, Italy. Distribution, speciation and chemometric data treatment. Chemosphere 2002, 49, 545-557. [CrossRef]

35. Ter Braak, C.J.F.; Šamilauer, P. CANOCO Reference Munual and CanoDraw for Windows User's Guide: Software for Canonical Community Ordination (Version 4.5); Microcomputer Power: Ithaca, NY, USA, 2002.

36. Chen, L.G.; Tsui, M.M.P.; Lam, J.C.W.; Wang, Q.; Hu, C.Y.; Wai, O.W.H.; Zhou, B.S.; Lam, P.K.S. Contamination by perfluoroalkyl substances and microbial community structure in Pearl River Delta sediments. Environ. Pollut. 2019, 245, 218-225. [CrossRef]

37. Cusack, D.F.; Silver, W.L.; Torn, M.S.; Burton, S.D.; Firestone, M.K. Changes in microbial community characteristics and soil organic matter with nitrogen additions in two tropical forests. Ecology 2011, 92, 621-632. [CrossRef]

38. Lauber, C.L.; Hamady, M.; Knight, R.; Fierer, N. Pyrosequencing based assessment of soil pH as a predictor of soil bacterial community structure at the continental scale. Appl. Environ. Microb. 2009, 75, 5111-5120. [CrossRef]

39. Andronov, E.E.; Petrova, S.N.; Pinaev, A.G. Analysis of the structure of microbial community in soils with different degrees of salinization using T-RFLP and real-time PCR techniques. Eurasian Soil. Sci. 2012, 45, 147-156. [CrossRef]

40. Zornoza, R.; Acosta, J.A.; Martínez-Martínez, S.; Faz, A.; Bååth, E. Main factors controlling microbial community structure and function after reclamation of a tailing pond with aided phytostabilization. Geoderma 2015, 245-246, 1-10. [CrossRef]

41. Li, Y.; Sun, Q.Y.; Zhan, J.; Yang, Y.; Wang, D. Soil-covered strategy for ecological restoration alters the bacterial community structure and predictive energy metabolic functions in mine tailings profiles. Appl. Microbiol. Biotechnol. 2017, 101, 2549-2561. [CrossRef]

(C) 2019 by the authors. Licensee MDPI, Basel, Switzerland. This article is an open access article distributed under the terms and conditions of the Creative Commons Attribution (CC BY) license (http://creativecommons.org/licenses/by/4.0/). 